\title{
Voluntary or Involuntary Childlessness? Socio-Demographic Factors and Child- lessness Intentions among Childless Finnish Men and Women aged 25-44
}

\author{
ANNELI MIETTINEN, M.Soc.Sc., Researcher \\ Population Research Institute, Väestöliitto, Helsinki, Finland
}

\begin{abstract}
Lifetime childlessness is expected to increase in the future. Recent research suggests that also voluntary childlessness in increasing among young adults. As childbearing decisions are increasingly based on individual preferences and choices it is believed that also those who do not favor family life with children can now more freely express their preferences. This study aims to investigate the prevalence of voluntary childlessness among Finnish young adults and factors associated with it. Data come from Finnish Social Relationships and Well-being Survey, conducted in 2008 among 25-44-year-old childless or one-child men and women. This study focuses on childless respondents $(N=1244)$. Two types of intentional childlessness are distinguished. Persons are classified as voluntarily childless if they do not intend to have children and prefer life without children. Those, who also have no intentions to have children, but whose personal ideal number of children is above zero are defined as persons who have relinquished parenthood intentions. Childhood characteristics are found to predict voluntary childlessness more, while socioeconomic circumstances and lack of a suitable partner explain relinquished parenthood intentions. Respondents 'personal accounts on the reasons behind their childbearing choices support the findings from multivariate analyses.
\end{abstract}

Keywords: childlessness, voluntary childlessness, postponement, Finland

\section{Introduction}

Recent years have witnessed increasing childlessness among young Finnish adults. In 2008 , 46 percent of women were childless at age 30 , among men the corresponding figure was 61 percent (Statistics Finland 2010a). While many of the childless young adults will have children later, it is expected that lifetime childlessness is also increasing all over Europe in the future (Frejka and Sardon 2006; Sobotka 2004). Although delaying of parenthood may explain large part of the increasing proportion of women and men remaining childless at each age (Testa 2007; Sobotka 2004), research has suggested that voluntary childlessness, understood to mean a deliberate choice not to have children, is also increasing in the industrialized countries (Sobotka 2009; Tanturri and Mencarini 
2008; Rindfuss et al. 1988). Normative constraints in family formation have become less rigid and childbearing choices are increasingly based on individual considerations and preferences. Persons who wish to have no children can now more freely express voluntary childlessness intentions (Tanturri and Mencarini 2008). The relationship between postponement of parenthood and voluntary childlessness is also somewhat unclear; for those who are ambivalent towards parenthood, the decision to remain childless may develop through consecutive decisions not to have children at a current moment.

In a recent European Value Survey from 2001, conducted in 15 European countries, the proportion of young adults aged 18 to 40 years who desired no children at all varied between two percent in Sweden to 16 percent in Germany (Goldstein et al. 2003). In Finland, the corresponding figure was five percent. While this modern type of childlessness - voluntarily childless or childfree life style - has received increasing attention among researchers, factors related to it are still very much understudied. This study attempts to investigate to what extend voluntary childlessness plays any role in family formation choices of young adults in Finland. In addition, it will look at the factors related to childlessness intentions, paying attention to sociodemographic, attitudinal and childhood factors as well as self-reported motivations behind childbearing intentions.

\section{Childlessness in Finland}

Permanent childlessness has been increasing in most industrialized countries especially among women born after the beginning of 1950s (Frejka 2008; Sobotka 2004). Despite of the general trend, there is still large variation across Europe between countries in the prevalence of lifetime childlessness (Frejka 2008; Sobotka 2004). Childlessness has been relatively low in the eastern European countries while some western European countries, notably and Germany, show markedly high proportions of childlessness (Frejka 2008). In Finland the relatively high overall fertility (1.86 in 2009, Statistics Finland 2010b) has been combined with increasing final childlessness (Andersson et al. 2009; Miettinen \& Rotkirch 2008). Prevalence of lifetime childlessness has also been on a higher level in Finland than in the other Nordic countries (Andersson et al. 2009). Currently 17-18 percent of Finnish women aged $45-49$ years are childless; however, the growing proportions of childless persons at younger ages suggests that the proportion may increase in the future (Statistics Finland 2010a; Miettinen \& Rotkirch 2008; Ruokolainen \& Notkola 2007) (Figure 1). Although the termination of the reproductive age span for men cannot be defined as straightforwardly as for women, proportion of childless persons among men at age 45-49 is considerably higher than among women, or 25-27 percent (Statistics Finland 2010a). 


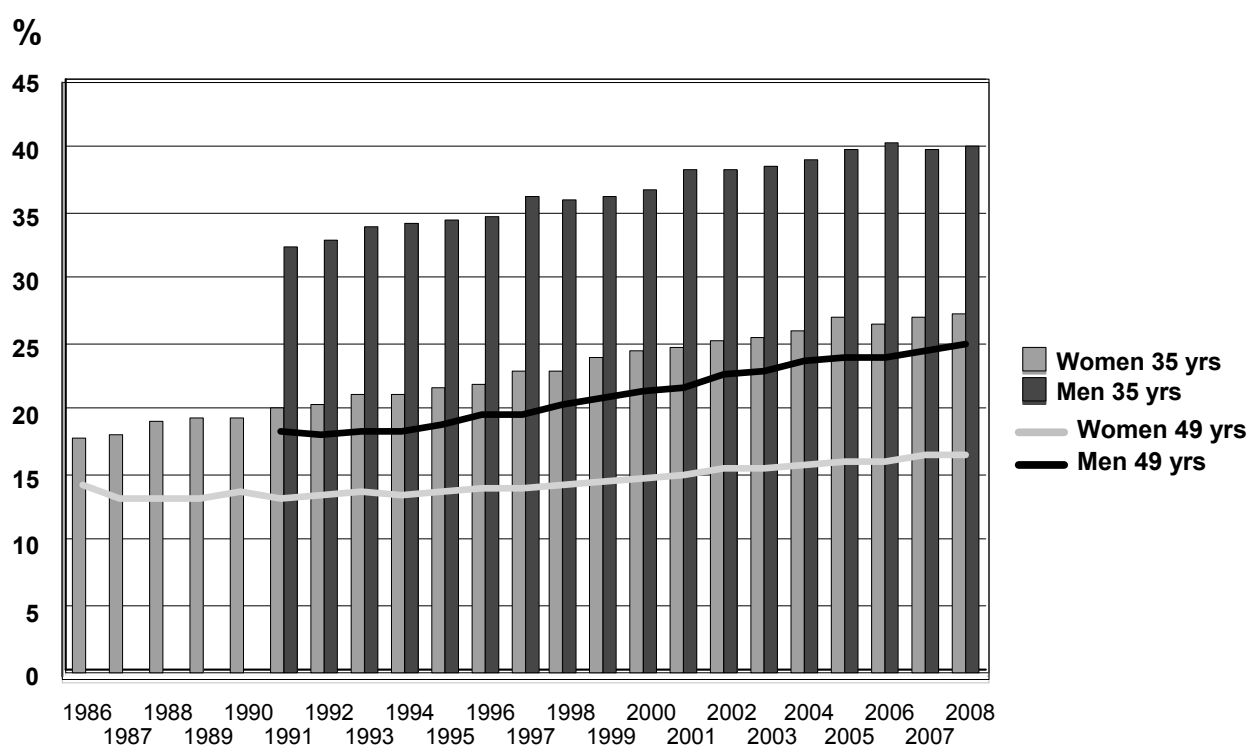

Figure 1. Proportion of childless persons at age 35 and at age 49 among women and men in Finland 1987-2008.

Note that figures in the table are retrieved from annual statistics on population by age and number of live births ever born to a person.

Source: Statistics Finland 1987-2010 (Population structure).

Although childlessness has gained increased research interest, we know relatively little of its components and factors related to it. In contemporary societies, childlessness has been more common among educated women (Gonzáles \& Jurado-Guerrero 2006; Gustafsson et al. 2002; Kiernan 1989). In Finland, however, the impact of education on childlessness appears to be reversed in the youngest cohorts as Andersson et al. (2009) find the highest proportion of final childlessness among women with low education (see however Nisén 2009). Men's fertility behavior is less studied but findings suggest that education, or higher socioeconomic position is positively related to men's childbearing (Kravdal 2007; Tölke \& Diewald 2003; Kravdal 2001). Research on determinants of lifetime childlessness among men has been scarce (Keizer et al. 2008; Kiernan 1989). In Finland, men with a high education show the lowest levels of childlessness among cohorts born between 1940 and 1960 (Nisén 2009; Nikander 1995).

The role of voluntary childlessness in explaining overall childlessness is not clear. It is generally assumed that childlessness in the past was mainly involuntary, related to later entry to marriage or living unmarried, or to subfecundity due to medical conditions (Rowland 2007; Poston \& Trent 1982). Contemporary childlessness is, according to this view, mainly based on voluntary decision not to bear children (at a current moment or ever). Traditional reasons - permanent sterility or living without union - may 
still explain modern lifetime childlessness. However, as the role of individual preferences and motivations has increased in childbearing choices among young adults, it is expected that voluntary childlessness will also increase (Tanturri \& Mencarini 2008; Hakim 2000). Until now, survey data indicates that the proportion of young adults desiring no children has remained low in Finland, ranging from two to seven percent (Miettinen \& Rotkirch 2008; Testa 2006). Although the data doesn't show any clear increasing or decreasing trends, the comparison over time or across studies is hampered by different measurements of voluntary childlessness.

\section{Theoretical considerations and earlier research}

Veevers (1980) has distinguished two types of voluntary childlessness. For some people lifetime childlessness results from a deliberate decision made already at early age not to have any children. Others may forgo parenthood after series of decisions to postpone childbearing, when the appropriate moment for the child never comes. Delaying parenthood may be a strategy to avoid a conflict between parenthood and education, or employment, particularly among women. It can also be related to increased indecision and ambivalence towards parenthood (Smallwood and Jeffries 2003). Postponing childbearing may provide a way to test childfree lifestyle, which eventually develops into a more explicit decision not to have children at all (Clarke and McAllister 1998).

Increasing proportion of childlessness at each age among young adults is believed to be mostly a consequence of postponement of parenthood to a later age (Sobotka 2009; Frejka \& Sardon 2006; Sobotka 2004). Young women and men want to receive a degree from education and establish a secure position in the labor market before they consider childbearing (Miettinen and Rotkirch 2008). Economic theories stress the role of women's education and employment in fertility decisions. In terms of gaining educational competence or earnings potential it is advantageous for a woman to postpone or forgo parenthood (Becker 1993; Blossfeld and Huinink 1991). Among men, income effect is expected to dominate in fertility decisions. The importance of costs related to raising children diminish with increasing income, thus men with higher income are more likely to opt for parenthood and to have more children (Becker 1993). Cultural and ideational explanations seek reasons for childlessness in changes in the attitudes and value orientations. Individualization, secularization and the importance ascribed to self-realization have meant that young adults can now more freely evaluate different pathways in life and pursue their own goals according to personal preferences. Childless, or childfree, lifestyle has become more accepted and people can more freely express a deliberate choice to remain childless (Tanturri \& Mencarini 2008). Family and children are no longer considered self-evident options in young peoples' lives, and particularly persons with a higher education are expected to be forerunners in this respect (van de Kaa 2001; Lesthaeghe 1995). 
While factors related to postponed or low fertility may also explain lifetime childlessness, decision to remain childless may stem from other factors. Hakim (2000 and 2002) has proposed a theory according to which women (and plausibly men too) develop preferences regarding family and working life already at early ages. Women who have a stronger preference for career advancement and working life and who are less prone to family may choose to reject parenthood completely. Preference for childlessness or a small family may also develop through socialization in childhood; living in single parent household, or having no siblings has been found to decrease fertility aspirations (Miettinen and Rotkirch 2008; Bloom and Pebley 1982).

Although comparable data on attitudes towards childlessness in Finland is scarce, surveys indicate that childless life appears to be relatively well accepted as over 70 percent (Nikander 1992, data covers only women) agree with that a woman doesn't have to have children in order to be fulfilled, and only 20 percent think that a person cannot be completely happy unless he or she has children (Paajanen et al. 2007). On the other hand, stronger pronatalist norms are expressed towards couples as 70 percent of Finns disapprove increasing trend of couples deciding not to have children (Paajanen et al. 2007).

Fragility of the partnerships may also contribute to postponement of childbearing or complete rejection of parenthood. Partnership remains an important prerequisite for childbearing (Spéder and Kapitány 2009; Miettinen and Rotkirch 2008; Testa 2007), and although most Finnish men and women start to cohabit or marry during their 20s or early 30s (Pitkänen and Jalovaara 2007; Nikander 1995 and 1992), partnership dissolution and re-formation can complicate realization of childbearing desires (Thomson et al. 2009). In addition, a significantly larger proportion of Finnish men never find a partner compared to women, which contributes to a larger share of men being unable to realize their childbearing aspirations (Nikander 1995 and 1992).

Although living without a partner is maybe one of the most important reasons for not having children, decision to remain childless can be made independently of partnership status. Tie between union formation and childbearing has weakened partly due to increasing fragility of the unions and long cohabitation period before marriage or before the couple starts to consider children (Thomson et al. 2009). It is possible that for those who find other life domains than family more interesting, a decision (not) to have children is entangled with a desire to live without a couple relationship.

Postponement of parenthood to a later age may also increase unwanted childlessness. While estimations of the prevalence of lifetime infertility have not provided conclusive results (for example Stephen \& Chandra 2006), infertility experiences are known to increase with age (te Velde and Pearson 2002; Notkola 1995). Decision to postpone childbearing until later may turn into involuntary childlessness once the couple is confronted with fecundity impairments. Toulemon (1996) has proposed that a very 
small fraction of childlessness among married couples is voluntary. Current estimates suggest rather low proportion of lifetime childlessness caused by primary infertility. Coleman (1996) has estimated that in contemporary Europe three percent of couples suffer from primary sterility. Similar findings are reported in Finland as Notkola (1995) using a retrospective data on female cohorts born 1938-65 finds that three percent of women suffer from primary infertility.

Relationship between voluntary childlessness and infertility can also be ambiguous. Women (and men) who wait long may confront unexpected infertility problems when trying to conceive. However, late marriage and delayed childbearing may reflect disinclination to parenthood (Veevers 1971), emphasizing voluntary factors which contribute to postponement of family formation. In addition, a proportion of impaired fecundity or permanent sterility may remain unobserved as those who do not plan to have children never try to conceive.

Childbearing decisions are essentially time dependent and childlessness intentions can be reversed as fertility desires are revised by life experiences. Previous studies have found that fertility intentions are sometimes poor predictors of future behavior, particularly when intentions are inquired at early age (Quesnel-Vallée and Morgan 2003; Schoen et al. 1999). However, negative intentions are found to be more stable than positive, and overestimation of future fertility more frequent than underestimation (Quesnel-Vallée and Morgan 2003). Increasing age and stable partnership status have been found to reduce instability of intentions (MacInnes 2006; Heaton et al. 1999). In contemporary low fertility societies fertility intentions have gained increased research interest as the recuperation of fertility is determined by the willingness and ability of young adults to have children. Intention for additional children provides a mediating variable in predicting future behavior and can shed light to the factors which are related to actual childbearing (Schoen et al. 1999; Rindfuss et al. 1988).

The aim of this article is twofold. First, I investigate the prevalence of voluntary childlessness among Finnish young adults. Voluntary childlessness is divided into two groups based on information on fertility intentions and preferences. I distinguish those who do not intend to have any children and whose personal ideal of the family size is zero children from those whose personal ideal number of children is one or above but who have relinquished parenthood intentions. Second, factors related to these two types of voluntary childlessness are examined. Attention is paid to socioeconomic, ideational and childhood factors in explaining the decision not to have any children. I also look at the reasons and motivations behind childlessness intentions as reported by the childless persons themselves. As socioeconomic factors appear to correlate with overall childlessness, it is of interest to examine, whether these differences are manifested in voluntary childlessness intentions. 


\section{Data and methods}

Data for this study come from Social relationships and well-being -survey conducted among childless and one-child adults aged 25 to 44 years living in Finland in 2008. Sample was stratified according to the number of children and age to ascertain that a fair amount of childless respondents particularly in the older age groups could be reached. Questionnaire included questions on fertility aspirations and ideals, attitudes towards gender relations, family and working life, perceptions related to childbearing and family formation, and sociodemographic background factors. Response rate varied between 34 and 37 percent among childless men and between 47 and 56 percent among childless women (Miettinen \& Rotkirch 2008). This study focuses on childless adults $(\mathrm{N}=1244)$ and their fertility intentions and ideals.

Dependent variable, intention to have children, was created from two separate questions (Table 1). Respondents were asked to tell their ideal personal family size as well as whether they intended to have a child or children in the future. Persons who did not intend to have a child, or who were uncertain about their intentions and preferred life without children (personal ideal 'no children') were defined as voluntarily childless. Those who had perhaps previously thought about having children (personal ideal 1+ children, or could not tell ideal number) but who currently stated that they did not intend to have any children, were considered as having relinquished parenthood. This group included also those who were uncertain about childbearing and couldn't tell their ideal family size. However, although they are classified as having relinquished childbearing, some proportion of them may still consider childbearing but feel ambiguous about it. Persons who intended to have children sometime in the future, and whose ideals of a family also included children were then categorized as intentional parents.

Table 1. Classification of fertility intentions among survey respondents.

Childbearing intentions
No intention to have
children

Uncertain about childbearing

Intends to have children

\author{
Ideal family size \\ Personal ideal $0(\mathrm{~N}=99)$ \\ Couldn't tell ideal number \\ $(\mathrm{N}=136)$ \\ Personal ideal $1+(\mathrm{N}=104)$
}

Personal ideal $0(\mathrm{~N}=2)$

Couldn't tell ideal number

$(\mathrm{N}=107)$

Personal ideal 1+ (N=163)

Personal ideal $0(\mathrm{~N}=0)$

Couldn't tell ideal number $(\mathrm{N}=90)$

Personal ideal $1+(\mathrm{N}=544) \quad$ Intentional parent
New variable

Voluntarily childless

Relinguished parenthood

Relinguished parenthood

Voluntarily childless

Relinguished parenthood

Relinguished parenthood

Intentional parent 
Variables measuring socioeconomic and demographic conditions include factors related to economic situation: employment (employed, student, unemployed/other), educational attainment (low, middle, high), income (personal income divided into three almost equal size categories), as well as demographic factors: age, living in a union (four categories: never in union, previous union(s) but no current union, previous unions and living currently in a union, living in intact first union), and place of living (urban, semiurban/ rural). Individual value orientation includes two factors: orientation towards work and religiousness coded both as dummy-variables. Childhood factors were measured with education of the parents (either or both of the parents having at least lower tertiary level education, both parents no or less than tertiary level education), a dummy for whether the respondent's parents had divorced before the respondent reached adulthood, and number of own siblings (no siblings, one or more siblings). Distribution of variables according to childbearing intentions is provided in the Appendix 1.

I employ multinomial logistic regression to analyze factors related to different types of childlessness. In the models, voluntarily childless and those who have relinquished fertility intentions are compared with those who intend to have children. These two types of voluntary childless persons are here understood to represent qualitatively different childlessness intentions. In the second part of the results section I describe self-reported reasons and motivations for childlessness intentions provided by the childless young adults themselves.

\section{Results}

The proportions of voluntarily childless and those who have relinquished fertility intentions grow with age (Figure 2). This stems partly from the way the sample was drawn. As the survey was conducted among persons with no children or with one child, the group under study becomes more selected with increasing age. Childless women represent about 50 percent and men about 65 percent of the total population in the age group of 25-34-year-olds. Among 35-44-year-old population, a little over 20 percent of women and over 30 percent of men are childless (Statistics Finland 2010a).

Voluntary childlessness is rather rare among Finnish men and women below 30 years of age. Among 25-29-year-old persons, five percent of women and three percent of men stated that they did not intend to have any children and preferred life without children. Among the oldest age groups under study, those aged 35 or above, 14 percent of women and ten percent of men were classified as voluntarily childless. Considering the proportion of childless persons among total 40-44-year-old population, it can be estimated that less than three percent of Finnish men and women above or close to the end of their reproductive age span are voluntarily childless. Looking at the proportion of voluntarily childless persons among the youngest age groups, there appears to be no indication that the role of voluntary childlessness in explaining lifetime childlessness will increase in the near future. 
Age is naturally related to forgone fertility desires, and parenthood intentions are abandoned with increasing age. However, close to a third of men below 35 years of age and little less than a fourth of women in the same age group stated that they did not consider childbearing though their personal family size ideal was not zero children. Although some of these respondents expressed more often uncertainty about childbearing rather than complete rejection of parenthood, one man in ten and about five percent of women in the youngest age group did not intend to have children although their personal ideal of a family included children. On the other hand, 10 percent of childless women and 20 percent of men in the oldest age group (40-44 years) still considered having children.

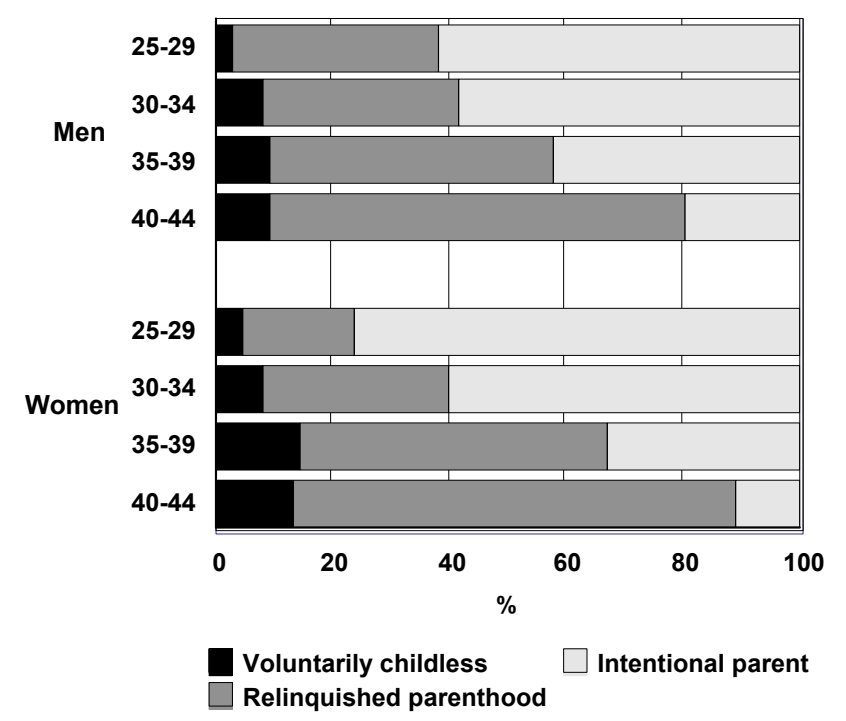

Figure 2. Childbearing intentions by age group, 25-44-years old men and women (\%).

Next, multinomial logistic regression is used to look at the correlates with different kinds of childbearing intentions. The results are presented in Table 2. Columns provide the effects of the covariates on the probability of expressing either type of intended childlessness against the probability to intention to have a child. Analyses are done separately for men and women as I expected gender differences in factors associated with childlessness intentions. 
Table 2. Multinomial logistic regression for childbearing intentions and sociodemographic factors, 25-44-year-old women and men. (Odds ratios).

\begin{tabular}{|c|c|c|c|c|c|}
\hline & \multicolumn{2}{|c|}{ WOMEN } & \multicolumn{2}{|c|}{ MEN } \\
\hline & & $\begin{array}{l}\text { Voluntarily } \\
\text { childless }\end{array}$ & $\begin{array}{l}\text { Relinquished } \\
\text { parenthood }\end{array}$ & $\begin{array}{l}\text { Voluntarily } \\
\text { childless }\end{array}$ & $\begin{array}{l}\text { Relinquished } \\
\text { parenthood }\end{array}$ \\
\hline \multirow[t]{4}{*}{ Age } & $25-29$ & 1.00 & 1.00 & 1.00 & 1.00 \\
\hline & $30-34$ & $3.28^{\star *}$ & $1.92^{*}$ & 2.59 & 1.29 \\
\hline & $35-39$ & $8.03^{\star * *}$ & $5.99^{\star * *}$ & $6.09^{* *}$ & $2.57^{\star \star}$ \\
\hline & $40-44$ & $37.68^{* * *}$ & $41.17^{\star * \star}$ & $10.38^{* * *}$ & $7.52^{\star * *}$ \\
\hline \multirow[t]{4}{*}{ Partnership } & Intact $1^{\text {st }}$ union & 1.00 & 1.00 & 1.00 & 1.00 \\
\hline & $\begin{array}{l}\text { Currently in union, } \\
\text { previous union(s) }\end{array}$ & .96 & .94 & 1.80 & $.51+$ \\
\hline & $\begin{array}{l}\text { No union, previ- } \\
\text { ous union(s) }\end{array}$ & 2.05 & $2.41^{* *}$ & 2.39 & 1.42 \\
\hline & Never in union & $2.61^{*}$ & $4.32^{\star \star \star}$ & $4.86^{*}$ & $3.31^{* * *}$ \\
\hline \multirow[t]{3}{*}{ Education } & Low & 1.00 & 1.00 & 1.00 & 1.00 \\
\hline & Middle & 1.26 & .96 & 1.35 & 1.23 \\
\hline & High & 1.03 & .95 & 1.08 & .67 \\
\hline \multirow[t]{3}{*}{ Employment } & Employed & 1.00 & 1.00 & 1.00 & 1.00 \\
\hline & Unemployed & .75 & 2.23 & 1.00 & $6.14^{\star *}$ \\
\hline & Student & .91 & $1.67+$ & 1.25 & 1.03 \\
\hline \multirow[t]{3}{*}{ Income } & Low & 1.00 & 1.00 & 1.00 & 1.00 \\
\hline & Middle & .48 & 1.14 & .70 & .87 \\
\hline & High & $.31^{*}$ & .79 & .32 & .88 \\
\hline \multirow{2}{*}{$\begin{array}{l}\text { Place of } \\
\text { residence }\end{array}$} & Rural & 1.00 & 1.00 & 1.00 & 1.00 \\
\hline & Urban-semiurban & 1.16 & .69 & .66 & .80 \\
\hline \multirow{2}{*}{$\begin{array}{l}\text { Work } \\
\text { orientation }\end{array}$} & High & 1.00 & 1.00 & 1.00 & 1.00 \\
\hline & Weak-moderate & .83 & .96 & 1.02 & .77 \\
\hline \multirow[t]{2}{*}{ Religiousness } & Not important & 1.00 & 1.00 & 1.00 & 1.00 \\
\hline & Important & $.50^{*}$ & $.63^{*}$ & $.23^{*}$ & .77 \\
\hline \multirow{2}{*}{$\begin{array}{l}\text { Parents' } \\
\text { education }\end{array}$} & Both low & 1.00 & 1.00 & 1.00 & 1.00 \\
\hline & Both/either high & .59 & .92 & $2.67^{*}$ & .76 \\
\hline \multirow{2}{*}{$\begin{array}{l}\text { Number of } \\
\text { siblings }\end{array}$} & $1+$ & 1.00 & 1.00 & 1.00 & 1.00 \\
\hline & No siblings & 1.36 & .77 & $3.12+$ & 1.46 \\
\hline \multirow{2}{*}{$\begin{array}{l}\text { Parents' } \\
\text { divorce }\end{array}$} & Yes & 1.00 & 1.00 & 1.00 & 1.00 \\
\hline & No & .63 & .88 & .81 & .95 \\
\hline
\end{tabular}

Logistic regression analysis confirms the importance of partnership status to childbearing intentions. Persons who do not have a partner (who are not living in a union) are more likely to reject or forgo parenthood. Voluntarily childless men and women are more likely to live without union although among men, voluntary childlessness is more frequent among those who have never found a partner than among those who currently do not live in a union but who have previous experiences of union(s). The impact of union status is more straightforward among men than among women. 
Although not having a partner is a strong predictor of voluntary childlessness, voluntary childlessness intentions are expressed also among those who live in a union. In the age group of 25 to 34 years, four percent of men and women living in a union stated that they preferred life without children. Among older age group, eight percent of men living in a union and 15 percent of women were voluntarily childless.

Socio-economic factors contribute only little to voluntary childlessness in Finland. Only income seems to be related to childlessness preferences as women with low income are more likely to be voluntarily childless. Among men, the impact of income is similar although not statistically significant. Educational attainment seems to have no relation to voluntary childlessness after age and union status were added to the models.

This, as well as the finding that work orientation shows no marked association with voluntary childlessness, runs somewhat against theoretical considerations which presume that voluntary childlessness is more common among women from higher educational groups, or among women with strong work orientation (cf. Hakim 2000). Economic theories suggest that particularly highly educated women are affected by the opportunity costs posed by childbearing and thus are more likely than others to delay or completely forgo parenthood (Becker 1993). Perceptions of the balance between working life and family and relatively generous governmental support to working mothers may contribute to that strong work orientation among (highly educated) women is not combined with childlessness preferences in Finland. The finding that also urban residency is not related to childlessness preferences does not lend support to that highly educated persons or urban residents are not forerunners of modern childfree life style in Finland.

In line with previous studies (Tanturri \& Mencarini 2008; Kiernan 1989), childhood factors appear to influence childlessness preferences also among Finnish adults, particularly among men. Voluntary childlessness is more common among men who are not very religious, who have no siblings or whose parents or either of them has at least lower tertiary level education. Women are more than men affected by their parents' divorce, although the effect is not statistically significant. On the other hand, the impact of parents' education on voluntary childlessness is the opposite among women; among them, the higher parental education is associated with lower likelihood of voluntary childlessness.

Results for relinquished childbearing show, that socioeconomic conditions as well as union status are related to delaying and finally abandoning parenthood. Women and men who are not living in a union are more likely to relinquish childbearing intentions. However, the impact is less marked, if the person has experiences of previous union(s). In fact, men who have experienced a disruption of a previous union are more likely to intend to have a child if they enter a new union compared to men who live in an intact first union. 
Socioeconomic factors contribute more to relinquishing parenthood intentions than to voluntary childlessness. Highly educated men are less likely to forgo parenthood than other men but once other factors are included in the models the impact of education becomes insignificant. Unemployment leads both men and women to abandon parenthood (among men statistically significantly). It is possible that men still presume the responsibility for the breadwinning in the family. Unemployment may pose a threat to man's economic competency and therefore, leads to relinquishing childbearing intentions. Among women, on the other hand, unemployment may increase uncertainty towards parenthood as only employed women benefit from earnings related maternity benefits. Economic considerations and uncertainty about the consequences of parenthood to one's situation may explain also why studying women are more likely to forgo childbearing.

Although urban residency was not associated with voluntary childlessness, it may be associated with 'postponement culture' as urban women are more likely to intend to have a child than their rural age mates who for their part express more often relinquished childbearing intentions in each age group. Childhood factors appear to be less connected with relinquishing parenthood than with voluntary childlessness. Religious women are less likely than others to abandon childbearing, while background of the parents or circumstances in one's childhood family do not explain forgone childbearing intentions.

\section{Reasons for deciding 'no'}

What are the reasons and motivations behind childlessness intentions provided by the childless persons themselves? Finnish Social relationships and well-being survey included also questions which asked respondents to agree or disagree if a given reason or motivation had been relevant in their decision (not) to have children or to postpone childbearing. Table 3 provides the proportions of those who considered the reason important or very important. Persons who had relinquished childbearing are divided into two groups according to their age as it was expected that the self-reported motivations may differ between the younger and older respondents. 
Table 3. Reasons and motivations provided by childless persons for their decision. Childless men and women aged 25 to 44 by childlessness intention. Proportion of respondents who agreed with the given statement (\%).

\begin{tabular}{|c|c|c|c|c|c|c|}
\hline & \multicolumn{2}{|c|}{$\begin{array}{l}\text { Voluntarily } \\
\text { childless }\end{array}$} & \multicolumn{2}{|c|}{$\begin{array}{l}\text { Relinquished } \\
\text { parenthood } \\
\text { Age group 25-34 }\end{array}$} & \multicolumn{2}{|c|}{$\begin{array}{l}\text { Relinquished } \\
\text { parenthood } \\
\text { Age group 35-44 }\end{array}$} \\
\hline & Men & Women & Men & Women & Men & Women \\
\hline \multicolumn{7}{|l|}{ Health motivations } \\
\hline Too old & 13 & 21 & 0 & 2 & 26 & 53 \\
\hline Partner too old & 5 & 7 & 0 & 2 & 29 & 16 \\
\hline Health reasons & 8 & 8 & 15 & 11 & 9 & 19 \\
\hline \multicolumn{7}{|l|}{ Economic reasons } \\
\hline Uncertain employment situation & 8 & 16 & 22 & 18 & 20 & 6 \\
\hline Uncertain employment, partner & 3 & 12 & 10 & 4 & 4 & 8 \\
\hline Uncertain economical situation & 5 & 18 & 24 & 20 & 17 & 11 \\
\hline \multirow{2}{*}{$\begin{array}{l}\text { Too small an apartment } \\
\text { Not enough support from the } \\
\text { society }\end{array}$} & 5 & 3 & 27 & 15 & 12 & 8 \\
\hline & 5 & 12 & 10 & 7 & 12 & 6 \\
\hline \multicolumn{7}{|l|}{ Career and education } \\
\hline Career opportunities & 5 & 18 & 22 & 33 & 7 & 5 \\
\hline Career opportunities, partner & 5 & 2 & 12 & 8 & 0 & 2 \\
\hline Finish education & 3 & 5 & 12 & 22 & 4 & 6 \\
\hline Finish education, partner & 5 & 5 & 5 & 7 & 0 & 1 \\
\hline \multicolumn{7}{|l|}{ Personal considerations } \\
\hline Want to do other things & 38 & 33 & 34 & 36 & 7 & 8 \\
\hline Would have to give up life style & 49 & 54 & 35 & 38 & 22 & 14 \\
\hline $\begin{array}{l}\text { Doesn't want to be tied to } \\
\text { children }\end{array}$ & 74 & 58 & 15 & 22 & 27 & 22 \\
\hline Feels too immature & 21 & 23 & 20 & 27 & 9 & 11 \\
\hline \multirow{2}{*}{$\begin{array}{l}\text { Would not be a good parent } \\
\text { Concerned about the future of } \\
\text { children }\end{array}$} & 51 & 51 & 15 & 29 & 14 & 13 \\
\hline & 26 & 32 & 20 & 16 & 14 & 13 \\
\hline \multicolumn{7}{|l|}{ Partnership } \\
\hline No partner & 23 & 20 & 58 & 41 & 48 & 38 \\
\hline Problems in partnership & 0 & 5 & 5 & 9 & 3 & 9 \\
\hline
\end{tabular}

Note: Although not all respondents were living with a partner, they were not excluded from reasons concerning partner to provide an overall picture of the importance of a specific reason to childlessness intentions.

Self-reported reasons further support the notion of the multifaceted picture of voluntary childlessness and relinquished fertility intentions. Personal considerations and ambivalence towards parenthood proved to be the most often cited motivations for voluntary childlessness among women and men rather than perceived economic or work-related barriers. A half or more than a half of voluntarily childless persons told that they didn't want to be tied up with children and felt that children would threaten their life style. Voluntarily childless persons were also less confident with their abilities to be a good parent. 
Economic uncertainty, employment and career related reasons appear to play only a minor role in a deliberate long-term decision not to have children. Only few men indicate these motivations, among women they are a little more frequent. On the other hand, their role grows when we look at the relinquished fertility intentions among younger respondents. Economical situation, uncertain employment and career ambitions are key reasons to forgo parenthood. Prolonged studies diminish also parenthood intentions in these age groups. Lack of a suitable partner prevents also many from trying to have children. Uncertainty about parenthood among younger age groups is often related to personal factors. Both men and women are concerned about having to change one's life style, or wanting to do other things first. This may be related to postponement culture, as particularly the highly educated young adults want to 'keep all doors open' and delay those decisions which are considered restrictive (c.f. Ketokivi 2002). Young women may also fear the double burden associated with combining children and family life with work. Health reasons for relinquishing childbearing are cited by 10-15 percent of the younger respondents. Although not directly inquired, infertility problems may explain some of the health reasons.

Among the older respondents, health conditions and old age become important reasons to forgo childbearing. Lack of a suitable partner is also cited as a major reason for not considering children among the older respondents. As almost half of those who did not currently live with a partner had had previous partnerships, fragility of the partnerships can contribute to relinquished intentions. Late entry into (new) union may also prevent childbearing as people consider themselves too old to have children.

Economic or work-related reasons play less important role in childbearing decisions among older respondents. Economic reasons for abandoning childbearing were cited more often among older men than among women. Older men were also more reluctant than women to give up their present life style, or to tie themselves up with small children.

These findings suggest that voluntary childlessness is related to personal preferences and motivations, which may be shaped by childhood context, rather than to life experiences and socioeconomic circumstances during adult life. Relinquished childbearing, on the other hand, seems to stem from recurrent decisions to delay and finally abandon childbearing in which particularly the lack of a suitable partner and economic and work-related constraints condition the decision making. However, personal motivations are also indicated as important reasons for relinquishing childbearing among younger respondents. It is also possible that norms still prevent particularly women from expressing deliberate rejection of parenthood and the decision to have children is postponed to a later age when it becomes socially more acceptable to forgo parenthood. 


\section{Conclusion and discussion}

The prevalence of childlessness among young adults has shown continuous increase during last decades in Finland as in all industrialized countries. Although this to a large extent is related to postponement of parenthood to a later age, it is expected that voluntary childlessness is also increasing (Sobotka 2009; Tanturri \& Mencarini 2008). The aim of this article was to investigate the prevalence of voluntary childlessness and its determinants among young Finnish adults. The article divided voluntary childless persons into two groups, into those who preferred life without children and did not intend to have any children, and those, who had no intentions to have children but whose personal ideal of a family included children. The first group was classified as voluntarily childless, and the latter as having relinquished parenthood.

The results showed that voluntary childlessness is rather rare in Finland. Although normative constraints to childfree life have diminished, only a small proportion of young adults express a deliberate wish to have no children. Below 30-year old childless respondents, only four percent wished to have no children at all. If we use the information on the prevalence of voluntary childlessness among women aged 40-44 years in this study, it can be estimated that currently roughly 14 percent of childless women at the end of their reproductive age span are childless due to voluntary rejection of parenthood. Marked increase in the extent to which voluntary childlessness will explain future lifetime childlessness seems also unlikely, as the proportion of voluntary childless persons among the youngest age group under study was considerably small.

Partnership status remains an important condition for childbearing and lack of a suitable partner was associated with relinquished parenthood among both men and women. Among men, lack of partnership was also associated with voluntary childlessness, among women voluntary childlessness was less related to union status. It is also evident that the fragility of partnerships contributes to overall childlessness although there are some signs that entry into new union may increase childbearing (see also Vikat et al. 2003). However, early breakup of unions and late entry into (subsequent) partnerships may prevent many from realizing their fertility desires.

Among older persons, childlessness was mainly related to abandoned fertility desires. Many (had) wished for children but due to circumstances - not finding a suitable partner, health conditions or other reasons - had relinquished childbearing. Although a fifth of childless men and one in every ten women in the age group 40-44 still planned to have children it is likely that many of them will not be able to fulfill their fertility intentions.

Voluntary childlessness appeared to be mainly connected with childhood factors rather than socioeconomic circumstances during adult life. Particularly among men, childhood home characteristics explained voluntary childlessness more than the other factors. 
Results suggest that voluntary childlessness among women and men is somewhat different. For men, religiousness, parent's low education and living with siblings in childhood reduced the likelihood to be voluntarily childless. For women, childhood home characteristics had less marked impact. Besides childhood factors, no distinctive socioeconomic or demographic group could be identified among voluntarily childless persons. Voluntary childlessness was more common among low income women but otherwise there were no marked differences between educational or socioeconomic groups. Contrary to presumptions, high education, strong work orientation or urban residency are not connected to voluntary childlessness in Finland.

In cross-sectional surveys, voluntary childlessness may be difficult to define and operationalize. In this study, a composite variable based on both fertility intentions and ideals was used. However, it was apparent that the crude classification ignored some important dimensions in childbearing decisions which would require a more detailed study. Particularly, uncertainty and ambivalence which appears to characterize modern childbearing decisions should receive more attention in the future. For many, decision not to have children may be a consequence of a process, where childbearing is postponed due to reasons related to relationship, personal considerations as well as financial and work-related constraints until it is too late to have children. Crosssectional studies fail to address these issues. In addition, this study did not address infertility experiences in explaining childlessness intentions. Although childlessness caused by infertility is understood to be involuntary, factors related to it may in many cases be the same as those explaining more voluntary intentions, particularly when we consider the role of voluntary postponement of childbearing and late entry into union in explaining increasing infertility trends.

\section{References}

Andersson, Gunnar, Marit Rønsen, Lisbeth Knudsen, Trude Lappegård, Gerda Neyer, Kari Skrede, Teschner, Kathrin and Anders Vikat. 2009. Cohort fertility patterns in the Nordic countries. Demographic Research 20(14): 313-352.

Becker, Gary. 1993. A Treatise on the Family. Enlarged edition. Harvard University Press, Cambridge, Massachusetts.

Bloom David E. and Anne R. Pebley 1982. Voluntary childlessness: A Review of evidence and implications. Population Research and Policy Review 1(3): 203-224.

Blossfeld, Hans P. and Johannes Huinink. 1991. Human capital investment or norms of role transition? How women's schooling and career affect the process of family formation. American Journal of Sociology 91(1): 143-168.

Clarke, Linda and Fiona McAllister. 1998. Choosing childlessness. London: Family Policy Studies Centre.

Coleman, David. 1996. New patterns and trends in European fertility. International and sub-national comparisons. In Europe's population in the 1990s. Edited by Coleman, David, pp 1-61. Oxford: Oxford University Press. 
Frejka, Tomas. 2008. Parity distribution and completed family size in Europe: Incipient decline of the two-child family model? Demographic Research 19(4): 47-72.

Frejka, Tomas and Jean-Paul Sardon. 2006. First birth trends in developed countries: Persisting parenthood postponement. Demographic Research 15(6): 147-180.

Goldstein, Joshua, Wolfgang Lutz and Maria R. Testa. 2003. The emergence of subreplacement family size ideals in Europe. Population Research and Policy Review 22(5-6): 479-496.

Gonzáles, María-José and Teresa Jurado-Guerrero. 2006. Remaining childless in affluent economies: A comparison of France, West Germany, Italy and Spain 1994-2001. European Journal of Population 22: 317-352.

Gustafsson, Siv, Eiko Kenjoh and Cecile Wetzels. 2002. The role of education on postponement of maternity in Britain, Germany, the Netherlands and Sweden. In: The gender dimension of social change. Edited by Ruspini, Elisabetta and Angela Dale, pp 55-79. Bristol (UK): The Policy Press.

Hakim, Catherine. 2000. Work-lifestyles choices in the $21^{\text {st }}$ century: Preference theory. Oxford: Oxford University Press.

Hakim, Catherine. 2002. A new approach to explaining fertility patterns: Preference theory. Population and Development Review 29(3): 349-373.

Heaton, Tim B, Cardell K. Jacobson and Kimberlee Holland. 1999. Persistence and change in decisions to remain childless. Journal of Marriage and the Family 61(2): 531-539.

Keizer, Renske, Pearl A. Dykstra and Miranda D. Jansen. 2008: Pathways into childlessness: evidence of gendered life course dynamics. Journal of Biosocial Science 40(6): 863-878.

Ketokivi, Kaisa. 2002. Vapauden lumo ja vastuun taakka: Perheen perustaminen pidentyneen nuoruuden kulttuurissa. [The facination of freedom and burden of the responsibilities. Family formation in a culture of prolonged adolescene]. Unpublished master's thesis at the University of Helsinki. Helsinki: University of Helsinki.

Kiernan, Kathleen. 1989. Who remains childless? Journal of Biosocial Science 21(4): 387-398.

Kravdal, Øystein. 2007. Effects of current education on second- and third-birth rates among Norwegian women and men born in 1964. Demographic Research 17(9): 211-246.

Kravdal, Øystein. 2001. The impact of individual and aggregate unemployment on fertility. Demographic Research 6(10): 263-294.

Lesthaeghe, Ron. 1995. The second demographic transition in Western countries: An interpretation. In: Gender and family change in industrialized countries. Edited by Mason, Karen O. and Ann-Magritt Jensen, pp. 17-62. Oxford: Clarendon Press.

MacInnes, J. 2006. Voluntary childlessness, fertility 'plans' and the 'demand' for children: evidence from Eurobarometer surveys. Centre d'Estudis Demogràfics.

Miettinen, Anneli and Anna Rotkirch. 2008. Milloin on lapsen aika? Lastenhankinnan toiveet ja esteet. [When is the right time for children. Expectations and barriers to childbearing]. E 34. Helsinki: Family Federation of Finland, The Population Research Institute. 
Nikander, Timo. 1995. Suomalaismiehen perheellistyminen. [Family formation among Finnish men]. Population 1995:1. Helsinki: Statistics Finland.

Nikander, Timo. 1992. Suomalaisnaisen perheellistyminen. [Family formation among Finnish women]. Population 1992:10. Helsinki: Statistics Finland.

Nisén, Jessica. 2009. Koulutuksen yhteys lapsettomuuteen. Lapsettomuuden koulutusryhmittäisten erojen tarkastelu suomalaisilla naisilla ja miehillä. [Educational differences in childlessness among Finnish men and women]. Unpublished master's thesis at the University of Helsinki. Helsinki: University of Helsinki.

Notkola, Irma-Leena. 1995. Uutta tietoa hedelmättömyyden yleisyydestä. [New information on the prevalence of infertility]. Suomen Lääkärilehti 1995(50): 865870.

Paajanen, Pirjo, Anneli Miettinen and Marke Jääskeläinen. 2007. Mielipiteitä ja näkemyksiä väestönkehityksestä, perheestä ja perheellistymisestä Suomessa 2002. [Attitudes and opinions related to population development, family and family formation in Finland 2002]. Helsinki: Family Federation of Finland, The Population Research Institute. Available from: < http://www.vaestoliitto.fi/@Bin/386316/ PPA+Suomi+2002.pdf $>$

Pitkänen, Kari and Marika Jalovaara. 2007. Perheet ja perheenmuodostus. [Families and family formation]. In: Suomen Väestö 2 nd renewed edition. Edited by Koskinen, Seppo, Tuija Martelin, Irma-Leena Notkola, Veikko Notkola, Kari Pitkänen, Marika Jalovaara, Elina Mäenpää, Anne Ruokolainen, Mikko Ryynänen and Ismo Söderling, pp. 115-167. Helsinki: Gaudeamus.

Poston, Dudley L. and Katherine Trent. 1982. International variability in childlessness: A descriptive and analytical study. Journal of Family Issues 3(4): 473-491.

Quesnel-Vallée, Amélie. and S. Philip Morgan. 2003. Missing the target: Correspondance of fertility intentions and behavior in the U.S. Population Research and Policy Review 22: 497-525.

Rindfuss, Ronald R., S. Philip Morgan and Gray Swicegood, G. 1988. First births in America: Changes in the timing of parenthood. Studies in demography. Berkeley (CA): University of California Press.

Rowland, Donald. 2007. Historical trends in childlessness. Journal of Family Issues 28(10): 1311-1337.

Ruokolainen, Anne and Irma-Leena Notkola. 2007. Hedelmällisyys. [Fertility]. In: Suomen Väestö, 2nd renewed edition. Edited by Koskinen, Seppo, Tuija Martelin, Irma-Leena Notkola, Veikko Notkola, Kari Pitkänen, Marika Jalovaara, Elina Mäenpää, Anne Ruokolainen, Mikko Ryynänen and Ismo Söderling, pp. 77-113. Helsinki: Gaudeamus.

Schoen, Robert, Nan Marie Astone, Young J. Kim, Constance A. Nathanson and Jason M. Fields. 1999. Do fertility intentions affect fertility behavior? Journal of Marriage and the Family 61(3): 790-799.

Smallwood, Steve and Julie Jefferies. 2003. Family building intentions in England and Wales: Trends, outcomes and interpretations. Population Trends 112: 15-25. Sobotka, Tomáš. 2004. Postponement of childbearing and low fertility in Europe. 
Amsterdam: Dutch University Press.

Sobotka, Tomáš. 2009. Sub-replacement fertility intentions in Austria. European Journal of Population 25: 387-412.

Spéder, Zsolt and Balázs Kapitány. 2009. How are time-dependent childbearing intentions realized? Realization, postponement, abandonment, bringing forward. European Journal of Population 25: 503-523.

Statistics Finland 2010a. Population structure and vital statistics by municipality 2008. Population. Helsinki: Statistics Finland.

Statistics Finland 2010b. Data on live births in Finland. [cited in October 2010]. Available from: $<$ http://www.tilastokeskus.fi/til/synt/2009/synt_2009 2010-0415 tie 001 fi.html $>$

Stephen, Elizabeth H. and Anjani Chandra. 2006. Declining estimates of infertility in the United States: 1982-2002. Fertility and Sterility 86(3): 516-523.

Tanturri , Maria L. and Letizia Mencarini. 2008. Childless or childfree? Paths to voluntary childlessness in Italy. Population and Development Review 34(1): 5177.

te Velde, Egbert R. and Peter L. Pearson. 2002. The variability of female reproductive ageing. Human Reproduction Update 8: 141-154.

Testa, Maria R. 2006. Childbearing preferences and family issues in Europe. Special Eurobarometer. Luxembourg: European Commission. [cited in October 2010]. Available from: $<\underline{\text { http://ec.europa.eu/public opinion/archives/ebs/ebs } 253}$ en.pdf $>$

Testa, Maria R. 2007. Childbearing preferences and family issues in Europe: Evidence from the Eurobarometer 2006 survey. Vienna Yearbook of Population Research 2007: 357-379.

Thomson, Elisabet, Maria Winkler-Dworak, Martin Spielauer and Alexia Prskawetz. 2009. Union instability as an engine of fertility? A Micro-simulation model for France. Working Papers 2/2009. Wien: Vienna Institute of Demography.

Toulemon, Laurent. 1996. Very few couples remain voluntarily childless. Population, An English Selection 8:1-27.

Tölke, Angelika and Martin Diewald. 2003. Insecurities in employment and occupational careers and their impact on the transition to fatherhood in Western Germany. Demographic Research 9(3): 41-68.

van de Kaa, Dirk. 2001. Postmodern fertility preferences: from changing value orientation to new behavior. In Bulatao, Rodolfo A. and J.B Casterline (eds.): Global fertility transition. Supplement to Population and Development Review 27: 290-331.

Veevers, Jean E. 1971. Differential childlessness by color: A Further examination. Social Biology 18: 285-91.

Veevers, Jean E. 1980. Childless by choice. Toronto \& Vancouver: Butterworth co.

Vikat, Anders, Elizabeth Thomson and Alexia Prskawetz. 2003. Childrearing responsibility and stepfamily fertility in Finland and Austria. MPIDIR Working Paper WP 2003-001. Rostock (Ge): Max Planck Institute for Demographic Research. 
Appendix Table 1. Distribution of sociodemographic factors by childbearing intentions, men and women aged 25 to $44, \%$.

\begin{tabular}{|c|c|c|c|c|c|c|}
\hline & \multicolumn{3}{|c|}{ Women } & \multicolumn{3}{|c|}{ Men } \\
\hline & $\begin{array}{c}\text { Voluntarily } \\
\text { childless }\end{array}$ & $\begin{array}{c}\text { Relin- } \\
\text { quished } \\
\text { parenthood }\end{array}$ & $\begin{array}{l}\text { Intends } \\
\text { to have } \\
\text { children }\end{array}$ & $\begin{array}{c}\text { Voluntarily } \\
\text { childless }\end{array}$ & $\begin{array}{c}\text { Relin- } \\
\text { quished } \\
\text { parenthood }\end{array}$ & $\begin{array}{l}\text { Intends } \\
\text { to have } \\
\text { children }\end{array}$ \\
\hline \multicolumn{7}{|l|}{ Union status } \\
\hline Never in union & 19.4 & 29.8 & 15.5 & 41.0 & 51.8 & 22.2 \\
\hline $\begin{array}{l}\text { Previous union(s), no } \\
\text { current union }\end{array}$ & 30.6 & 28.7 & 17.4 & 23.1 & 15.4 & 16.3 \\
\hline $\begin{array}{l}\text { Previous union(s), } \\
\text { currently in union }\end{array}$ & 29.0 & 23.6 & 31.4 & 20.5 & 16.2 & 30.0 \\
\hline Intact first union & 21.0 & 17.8 & 35.6 & 15.4 & 16.7 & 31.5 \\
\hline \multicolumn{7}{|l|}{ Education } \\
\hline Low & 24.6 & 28.6 & 22.2 & 41.0 & 53.3 & 40.2 \\
\hline Middle & 49.2 & 41.2 & 37.8 & 30.8 & 27.0 & 29.9 \\
\hline High & 26.2 & 30.2 & 40.0 & 28.2 & 19.7 & 29.9 \\
\hline \multicolumn{7}{|l|}{ Employment } \\
\hline Employed & 4.9 & 10.4 & 4.7 & 0.0 & 17.2 & 3.3 \\
\hline Unemployed/not working & 19.7 & 24.2 & 23.7 & 22.6 & 15.4 & 21.7 \\
\hline $\begin{array}{l}\text { Student } \\
\text { Income }\end{array}$ & 75.4 & 65.4 & 71.6 & 77.4 & 67.4 & 75.0 \\
\hline Low & 22.6 & 22.1 & 19.4 & 23.1 & 29.6 & 17.0 \\
\hline Middle & 56.5 & 54.8 & 54.3 & 56.4 & 49.0 & 58.9 \\
\hline High & 21.0 & 23.2 & 26.3 & 20.5 & 21.4 & 24.1 \\
\hline \multicolumn{7}{|l|}{ Place of residence } \\
\hline Urban-semiurban & 77.4 & 72.1 & 76.3 & 66.7 & 63.5 & 73.7 \\
\hline Rural & 22.6 & 27.9 & 23.7 & 33.3 & 36.5 & 26.3 \\
\hline \multicolumn{7}{|l|}{ Work orientation } \\
\hline Weak-moderate & 67.7 & 69.8 & 70.4 & 76.3 & 73.3 & 72.7 \\
\hline High & 32.3 & 30.2 & 29.6 & 23.7 & 26.7 & 27.3 \\
\hline \multicolumn{7}{|l|}{ Religion } \\
\hline Important & 25.8 & 34.9 & 34.1 & 15.4 & 20.8 & 24.5 \\
\hline Not important & 74.2 & 65.1 & 65.9 & 84.6 & 79.2 & 75.5 \\
\hline \multicolumn{7}{|l|}{ Parents' education } \\
\hline Either/both middle/high & 30.6 & 33.7 & 47.6 & 46.2 & 24.5 & 39.6 \\
\hline Both low & 69.4 & 66.3 & 52.4 & 53.8 & 75.5 & 60.4 \\
\hline \multicolumn{7}{|l|}{ Number of siblings } \\
\hline 0 & 14.8 & 8.0 & 9.8 & 18.4 & 9.5 & 8.0 \\
\hline $1+$ & 85.2 & 92.0 & 90.2 & 81.6 & 90.5 & 92.0 \\
\hline \multicolumn{7}{|l|}{ Parents' divorce } \\
\hline No & 74.2 & 83.1 & 80.6 & 76.9 & 79.7 & 81.6 \\
\hline Yes & 25.8 & 16.9 & 19.4 & 23.1 & 20.3 & 18.4 \\
\hline $\mathrm{N}$ & 62 & 264 & 634 & 39 & 245 & 273 \\
\hline
\end{tabular}

